\title{
The Newsbooks and Letters of News of the Restoration
}

ON Monday, 25 June 1660, the houge of commons resolved ' that no person whatsoever do presume at his peril to print eny rotes or proceedings of this house without the special leave and order of this house.' On 0 July 1662 a question evell arose about the publication of the debates of the Irish parliament in the English Intelliyencer, and a letter was sent from its Speaker to Secretary Nacholus asking him to prevent it. ${ }^{1}$ The disability thas imposed on the printing press enhenced the special importance of the written compilations of news even more than the severe censorship maintained in the reign of Charles $\amalg$, for they supplied a want which the 'newsbooks' could not. As a collector of news the writer of letters bf intelligence was in a better position than any one else to write a nerrsbook. Ho had his oftice (where the folio sheets that he wroto were multiplied by copying clerks) and his correspondents all over the kingdom, many of whom received his papers free of chargu, or on rednced terms, on condition of supplying news. Owing to the delay in 'composing' printed matter thero was no very great difference in the amount of time required to set up and print off a newrbook, and that tuken to multiply a necessarily more limited number of written papers of news by the aid of several clerke. In the fuct that late news could be immediately aulded the 'letter of intellifence ' or 'of news,' as they were called, had the advantage of the newrbooks. For this purpose it was customary to leave a wide margin, which will generally bo found to be written on lengthways. Their great defect was their expense. And, as this restricted their circulation to the higher classes and the coffee honses, their long inmunity from the censare und other restrictions is at once explained. Five pounds a year was the castomary subscription for letters of new's, while the newsbooks were sold at the price of a penny.".

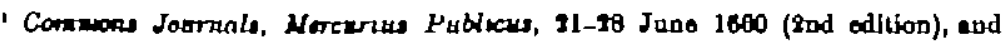
Irieh Contrors Jourzals, li. 91-6.

'The ocet of the letters of intelltgence bs giren in Steto Paperh Domentic, Car II, 275, no 50 (1670). Anthooy a Wood paid his Ortord bookiflar 2s. "quarterldye ' for both the ' newrbooks' down to the time of the Garalle. He purchased the Luador Garelle through a friend in London at a penay each (Wood's Lste, ed, by A.
} 
At the end of the Protectorate there were two editions of the government newbbook, the one entitled Mercurias Politicas, the other the Publick Intelligeneer, publinhed on Tharsdaye and Mondeys re. spectively, and written by Marchemont Nedham. No others were permitted. Each newbook contained the news for the eeven days previous to its date of issue; consoruently the tro overlapped erch other very much and it was only necessary to subscribe to one of them. These arrangements continned nntil the year 1664, when they became consecutive and were paged and numbered together (as if one periodical) irrespective of their titles. They were generally spotien of collectively as 'the newsbook' and sometimes styled the 'intelligence ' or 'diurnall,' for their titles are rarely mentioned and as a rule wero changed witl the mriters. Several refsons combined to bring Nedham into disgrace with the Rump in 1659. The ostensible caure $\mathrm{was}$ his disreputable private life, but the secret fear that his powerfal and venal pen might be sold to the enemies of the Commonwealth had the greatest weight.

Other newsbooks which had existed prior to the destruction of the licensed press by Cromwell rere suffered to renppear. Tro - the Faalfull Seout (no. 1, 22-29 April)-a title cbanged with its twelfth namber to the National Scout, and again with no. 14 to the Loyall Scout, and the W'eekly Pout (no. 1, 3-10 May)-were on 16 and 19 Jnly respectively marked 'published by special authority.' A third, the IVeckly Intelligencer of the Commonicealth (no. 1, 3-10 May), clearly possessed this anthority, but did not openly elaim it. It is posaible that Thomes Scot, the secretary of state, salaried a number of writers at this period, so that Nedham's monopoly could not bo renewed. Aubrey in his life of Berkenhead' say's thet forty shillings was the fee for writing a pemphlet, and, as in AIcrcuritus I'olstecus, a Pricate C'on. ference betrocen Scot and Nedham concernmy the Present Affairs of the Natiou (publiahed in 1660), Nedham is made to say in connexion with his final dismissal ander MIönck, "There's four pound a wetk gone beside advertisement halfcrotrns,' the inference is justified that two pounds was the fee that they all (Nodham in the end included) receired for each pamphlet of ners that they wrote. With so much competition (there were seven in all) the work could not have heen very remunerativa.

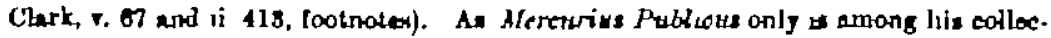

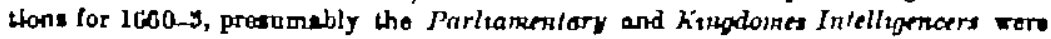
lost or given away. The Neses for 3t Septomber lass anations the people that the

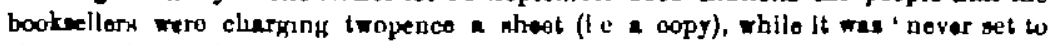
theill at abora $x$ fourth part of tie price' For tho booksellers to make their prott therefore it also must bavo been retelled at a panng, and not a balipeuny, as Niebols inferrod from this otetement. Tha yoution is aleo set at roat by H. Peacham's The Worth of a Penny (ed. 160-1).

'Briof Liter, ed. by A. Olert. 1. 10.8. 
On 13 May 1659 Nedham had been deprived of his pension and prohibited by the hodse of commons from 'writing the weekly intolligence,' and an old anabaptiat preacher-one John Cannoordered to take his place. He commenced the Morlerate Informer (no. 1, 12-19 May) in opposition.' Canne's sppointment excited deriaion, one pamphlet (Chester Queries) asking whether he 'did not his brother Merenry to accommodate him with those four Latin words he made use of in his newabook, vir. Bellum epiccopale and Bellum presbyteriale;" and if he did wo what such a ecantling of the language of the beast might stand him in,' with a reference to his project of making 'the days of the week (commonly called Sunday, dc.) Ansbaptista, like himself.' Bat the Maderate Informor soon came to an end, no donbt oring to the anthorizetion given to five other newrbooks-clearly through Canne's incompetence. On 15 August Nedham recovered his post. He bad witten a book againat the royal cause. No more was heard of his morala, and the pamphlet already quoted pertinently inquires 'whether Mr. Nedham's writing the Currant again be not a plain confutation of the book he lately published entitled Interest will not Lie.' Hovover, the monopoly of news had been aboliahed."

Two other newsbook appeared during the interval and decerve ettention They were both entitled $A$ Particular Adorce, \&c. (no. 1, 23-80 June) and Occurrences from Foreign Parts, dc. (no. 1, 28 June-6 Jaly), and came out twice a week, altarnately giving the leading place to the firet and second title. Their author, Oliver Willinme, was the asaignee of a patant for advertising offices grented by Charles I to Captain Robert Innes in 1687 for the term of forty-one years, and not including anything of the natare of a nerrobook.' Nedham (and it is clear not Canne) pras attacked

- He could not here reteined the wniting of Meresures Poluticus, for the Maderate

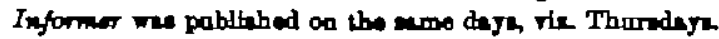

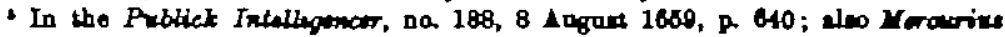

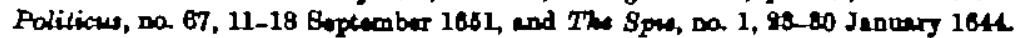

- In addition to the periodibale montioned in tho toxt the followine eppeared

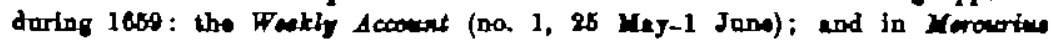
Politicus, 1-11 Anfort, the Diurnal th alladed to (this boworer is probebly ane of the

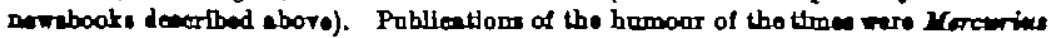

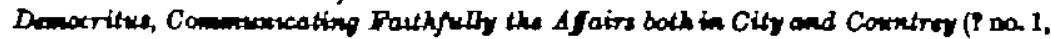

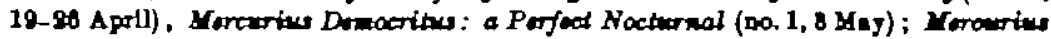

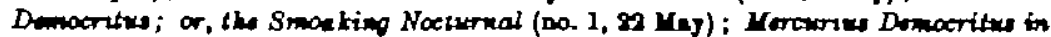

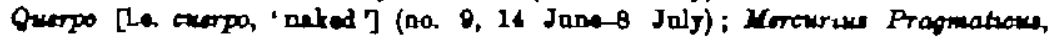

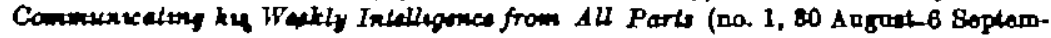

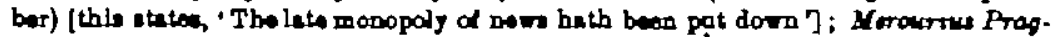

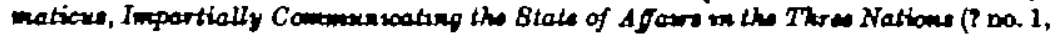
16-28 Dosomber).

Yecurwe Pragmatious (dimply) wa in andeted pamphlot (pobliched on 20 June) and not a partodieal, which states thet 'poor old Preg'- poor Judee' (Le. Nedhem)-hed bat his pention. All these were ephemeral.

1 8.P., Dom., Ohese I, 878, no. 75; 1 Prokubition to all Pereons who haw wh wp

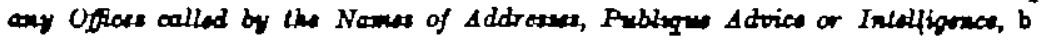


by him in Ocearronces for 5-12 and 12-19 Joly for attempting to suppress his newsbooks; but, commencing with $19 \mathrm{July}$, they both พөre also 'published by authority.' With 29 July they added 'a true account of the daylie cocurrences from Westminster' to the foreign news and "advice" (i.e. advertisements), and Williams, as wo are aftarwards told, "kept up a constant correspondence" with Thomas Scot, whose organ his newsbook mny be considered to have been in preference to any of the others. On 6 January 1689-60 A Partucular Adrice changed its lending title to $A n$ Exact Accompt of the Dally Procedings in Parlunent.

A new journalist appeared at the end of December 1659 with an unauthoriged newsbook which, unlike the rest, was not a revival. His name was Henry Aluddiman, and the importance of his work has been obscured in modern times through a series of mistakes. Born in 1629, he was baptized at St. Afartin's-m-the-Fields on 5 Febraary, and educated at St. John's College, Cnmbridge, where he was entered as a pensioner in 1647 . He is probably the anthor of the pamphlet published in 1659 (11 June) ander his initıals, H. M., A Pair of Spectacles for this Purblaude Nation, violently attacking the Rump as 'mungrel new Athenian republican tyranta,' in a munner which leads one to suppose that his family had suffered for their royalism, although his father, Edward Muddiman of the Strand, had boen nominated a collector of the assessment for St. Martin's-in-the-Fields for Fairfar's army in 1645. At the coronation review also, when the city forces were mustered in eighteon regiments before the king in Hyde Park on 7 May 1661, hus unole Sir William Muddiman commanded the lord mayor's troop of horee, 'all citizens;' ' for state before him was led a good. like horee, with bridle, saddle, and furniture, after the Indian manner, and $a^{\prime}$ tall, sirarthy-complexioned man leading him, clad also in a loose garment, cap and boots or buskins after the same manner'-in allusion to Catherine of Braganxs's dorry of Bombay." When General Monck's brother-in-lnw, Clarges, whom Ludlow describes as a 'known royalist, arrived un Inondon from Scotland in Docember 1659, and commenced publishing pamphlet on wat was evidently a plan preconcerted with Monck, Henry Minddiman, who down to that time had bean a schoolmaster, also began under his directions to issue a newsbook." He had, he says, 'never writ anything of this eort till entreated to it for a juet

Oliver Willemen and no. I of A Particular Adruce. See more of hin to the present -ritar's article on 'The Eerly Hatory of London Advertisiag.' Nireteenth Coniwry and AfLT, November 1907

- Hist. Hanuecipts Contmisnon, Sth Report, App. p. sos

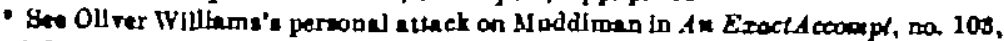

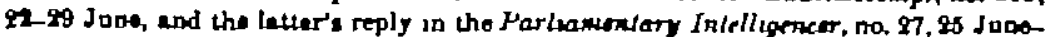
9 July 1600, On YU December (the dey of bene of the Porluamentary Intellugencer) Cleves wrote to Chamble, 'The scene of affairs is mach altered here in one week, as 
vindication of bis excellency and the army, to give faithful intelligence of their transactions, which were so basely and falsoly represented by the pamphleteers then in being.' Muddiman issued the first number of his Parlianentary Intelligencer in opposition to the Publick Intelligeneer for Mondays, 19-26 December 1659, meiking it Nunquam sera ent ad bonas mores ria. His object being to "represent the numbers that desired a free parliament" he was compelled to ' pition being cast apon' those for whom he wrote and 'to free' himself from Williams's 'prying master,' Bcot.

As General Monck was at the time about to march down from Scotland to support the Romp against the Engligh army leaders, his nowsbooks, while not concealing their object, naturally also supported the parliament, although in private life he was at no paine to disenuble his hatred for the Rump and its membera. ${ }^{10}$ Giles Dury joined him ten days later as his asaistant, and a Tharsday edition of the newsbook in opposition to Nedham's Mfercurrus Pollticus was started. The ehort title of this, Mercuritu Ptublicus (no. 1, 29 December-5 January 1659-60), was a daring revival of the old royalist Mereurius Publieus of 1648 , though it did not (like the older journal) add 'for the further discovery of that mystery of iniquity the present parliament at Weitminster and the timely information of the abused people of England.' Certain scoticisms are observable in the Parliamentary Intelligencer about this time (e.g. Fingburgh for Finsbury), which show that Dury was a Scotsman. General Monck appeared in London on 9 Fobruary, and, as addreses in farour of a freo- parliament were showered upon him on his way, the newgbooks ensured a truthful account of them as

Jo0 oney percoire by the eneloced diurnal, which in a book pabltahed by ing direc. tlome, for I have been a great printer sines I camo hither Capteln Good win will ahow jou two printed piecos of my contrivanos: ono is Hypocriter Uninatied, and tho other is called 1 Letior from a Colonal in Scotlond to an Oficor at Iondon, ac. (Lopborne-Pophan MSS, 1699,p. 137) Captein Goodwin mant bave been the writer of

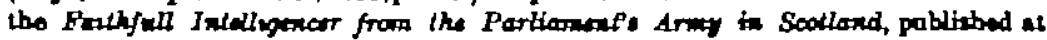
Edinbureh (na. 1, Toeeday, 29 Norempar, to Betarday, 8 Decomber) and printed by

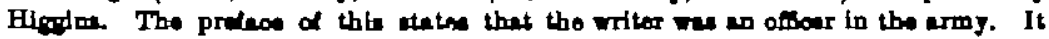
contalme an atteck opon the ' numfrowe and aneoath eatalogue of lyes' aboot Manok in the ' leto Politicus, commenting Thardey, the 17th of Forember.' This, and not

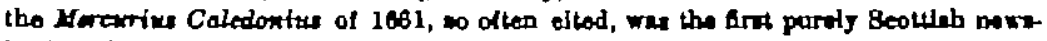
book, writton as woll al printed in Seotlend.

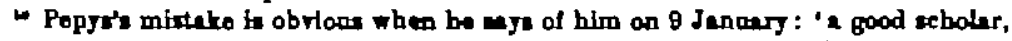

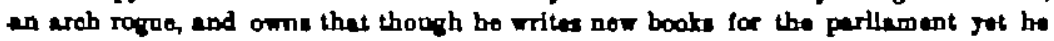
dif declero that be did it only to got mones, and did telk rerg bacely of meny of

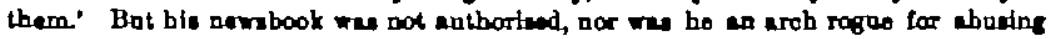
thoen who did not pey him. Pepre was a ceemel nequenatence, elert to the trechorous Downing, and the bet pernon likely to here bed Honet's plane conted to him. As there were then nomber of nornbooks 'publiahed by nathority' Pepse voold

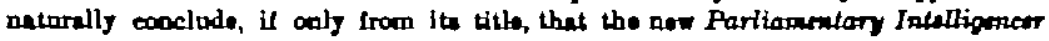
wes jot enotber addition to the list The lato Protemor 2IRson (Lifo of Millos,

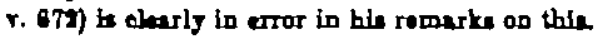


well as of his movements. To counteract the effect of this, fabricated addresses, such as the Watermen's address of congratulations (obtained by fraud) and Barebones' Petition, presented to the Rump, were et out in fall in Willisms's newsbooks. ${ }^{11}$ From 20 Febranery until the conncil of state's authorisation the Parlianntary Intelligercer was marked, 'Non sic minantia pila. Quan tutatur arkor.' On 9 January it had been marked, 'Facile est imperiur in bonis (Plaat. in Mil.).' An attempt to supprese it seems to hare been made and stopped by Thurloe (pho returned to office with the secluded members on 21 February). From the passage in an Exact Accompt alreedy referred to, the Post, Scout, and Weekly Inielligencer collopsed then or a fer veeks previonsly.

On the diesolution of the Long Parliament (16 March 1659-60) one of Monck's council of atate's first acts was to discharge Nedham and anction the Parliamentary Intelligeneer and Mereurius Pullicus to 'go forward,' as Wood eays, in lieu of Nedham's two newrbooks. The Parliamentary Intelligencer no. 14, for 26 March2 April 1660, was the firat number "by order of the conncil of state ' (no. 13 was for 12-19 March), and in it the order was set out by which Nedham was discharged and Maddiman and Dury anthorised to issue their two newsbooks, the former on Mondeys and the latter on Thursdays. ${ }^{19}$ By the next number (no. 16, 2-9 April) Nedham in addition was 'prohibited,' the Btationers' Company being ordered to soe that no other newabooks were publiahed on the same days. Nedham continued his newrbooks nevertheless until 12 April (no. 815 of Aferentius Politicus) and then sbeconded. His Mereurius Politicas and Publek Intelligencer were prithout a week's delay than carried on by Williams, the only difference being an alteration in the fall title, their renumbering, and the addition of a quantity of advertisements. Williems bad also issued a new Perfect Diurnal of the Daily Praceedings in Parliamert on 21 February. ${ }^{13}$ In the meantime Muddiman had been busy editing the papers

"An expoeare of the Wetermen's eddres by Prjane, 'A Deolention of all the Watermen in end about the CSty of London between Gravesend and Btenen; or, a Hoe and Cry eftar Calonel Whition and bis Decoys' (roprinted in Jahn Williame's A Happy Hardfull).

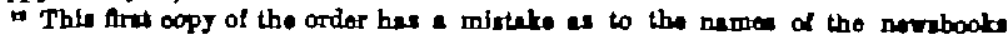

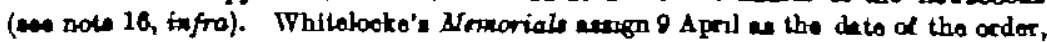
and aro vrong. Mr. H. R For Bourn (Exghsh Newpapors, L 24) gives an acoount of the origin of the two nowrabooke which is contridleted by the fete in orery detall.

- The Porfact Dramal was pablished on week days from 21 Pebrany to

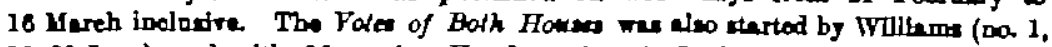

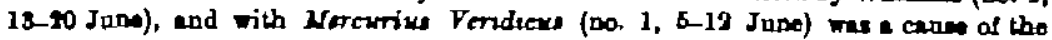
honis of commone resolution of 28 Jane Other nowabooks in 1660 rere the Nomethly Intellngener (na. 1, Decomber-Januery 1659-60), a follo of olght paces; Mercurtus Axliew; or, the Cowrt Horcury (? no. 1, 2-9 April); London's Dowrmal (no. 1, 1-8 Pobraty); and Yorewrims Civicss (? no. 1, 10-17 April). In a differont

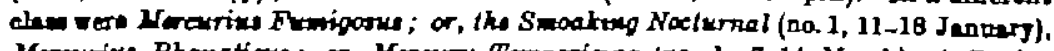
Merewive Phomaticus; or, Merewry Temporising (Do. 1, 7-14 Nereb), A Pofoct voL. IXIII.- $\rightarrow$ No. xo. 
printed by Blonck. Of these by far the most important was the deciaive Remonstrance and Address of the Army, signed by alrout forty officers and first presented by Charles, Lord Howard, on 9 April. It was then printed by Macock 'for Henry Muddiman, gent.,' by a epecial order eet ont on the title-page directing the lntter to print and publish it, and was circulated for the signature of the rest of the offeers. The king's restoration withont bloodshed was the result of this docament, which bound the signatories to obedience to whatever the forthcoming convention parliament should decide. ${ }^{14}$ These were services for which not only his newsbooks crentually became official, but also ho received, by order of Becretary Nicholas, the privilege of free postage," by which his letters of news were circulated without charge, and letters which contained intelligence were franked to him at his own private office, the Beven Stars, in the Strand. In return be supplied intelligence to the government. On Dury 'giving orer,' probably with the cessention of the euthority of the council of state at the end of May, and orving to Mnddiman's gervices no longer being required by Monck, Oliver Williams with considerable effrontery set np a claim to the sole right of publishing newsbooks (on the strength of his patent of 1637) in $A n$ Fxact Acconpt for 22-29 June 1660." Williams's pretensions led to the revival of the system of licensing newsbooks, and only the Pallamentary Intelligencer and Mercurius Pullicus were now suffered to

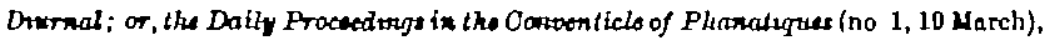

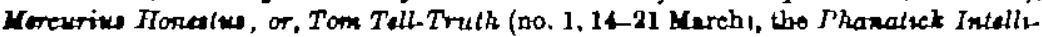

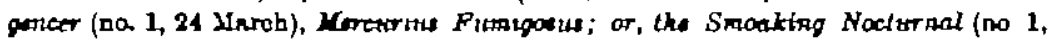

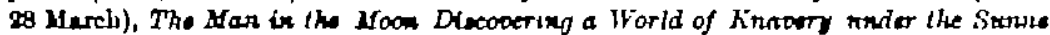
(no. 1, 19-28 April), undetod numbers of Metrourtus Frtrigoses; or, a Porfot Noctwonal, Herlunes Pharations (no. 1 [? $28 \mathrm{May}$ ], en atteot upon Lilly the astroloper), end The Wardering Whore (extromely courrilour-no. B, 12 Decomber).

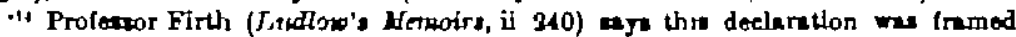

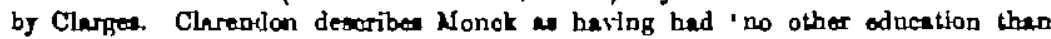
Datoh and Deronahire.' Clerge eren drow the drafte of his lattore (there ere many emong the Britleh Blawom manuscripte), bat wae not himsole very litarato, if the pan-

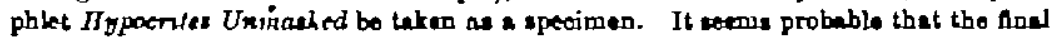
form of all Lonck'n doeomonte poblinbed through Kaddiman'e printor, Mscock, whe given to them by Moddimen, end that Dury was brooght down from Boothend to hetp hlm, in order that he might bo fren for the purpone. This would expleun Darg's oatandibly writing Mercirius Publecte daring tho brief period orer which the connol

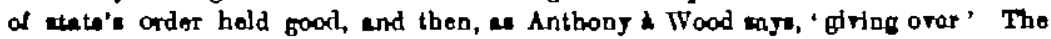
king's lotter to the army has a direction by BIonek to Siddiman to pablesh it wot oot on tho titla-pago (28 Hay). and ho al wo publlahed A Narratice of tho Procerdings of the Fleet on 23 Docornber 1059. In letor year Yuddımen mems to hero boen the anthor of tho Arat conptete trandation of Enemas's Colloquice (by H. N., cont., 1671)

is 8.P, Dom, Cheries II, 160, no. 149, paragraph 1, and 150, no 01 .

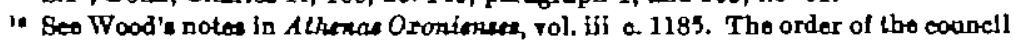
of thate is incorrectly wot ont in the Parlinamentary Iniallegercer, no. 14, and leave: it to be interred that Dary wes to write the Parliamontary Iniehtanacor, and on Tharedays, wherest this wh the Monday's odition. The mirteko was corrected In noe. 15,16 and the nocecting nambers. Nichole (Literary Arecdoles, ir. 62), copy. 
appear. Henry Muddiman then becsme sole journalist of England and Bootland for the next three years as regards printed matter. And as he also supplied the Fritten news his was even a greater monopoly than that of L'Estrange, who supplanted him." Henceforth for many years the privileged newbbooks and succeeding official newspapers that took their place were without any competition, though they were themselves restrieted in what they were allowed to publish.

At the commencement of June 1660 Roger L'Estrange pablished a book entitled L'Estrange lis Apology, setting out a number of forgotten pamphlets and broadeheets which he hed written in the royel cause during the pest year. His ostensible and somewhat far-fetched motive was that he had been accubed of being Crommell's instrument, but his real sim was no obtain preferment for his ervices and sufferings. He considered that his orm appointment as Nedham's successor was his just due for his exertions as royalist pamphleter, and the collection of extracts from Nedham's newsbooke referring in insulting terms to the king, whioh wes publiehed on 7 September 1660 under the title of $A$ Ropofor Pol, was, there is no donbt, written by him and with the motive of rendering it impossible for Nedhem to be resppointed in case he recented, as he had done once before. ${ }^{10}$ At this date the Parliamentary Intelligencer and Mercurius Publicus prere no longar privileged, the conncil of atste's authority heving expired with the council itself. Nothing however was done for him. On 2 November Bir John Berkenhead was appointed master of the facuities. He had written

ing trom Chelmen (Lifo of Ruddiman), wete out the inoorreot order, aleo attribetint it to na. 16 (In ordar to meke it agres with Whitatocke's mistake a to the dete). As

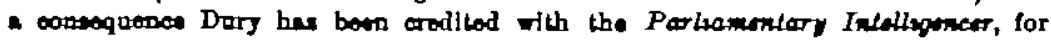
whlch be was nover at any time reaponalble In Nichabs's liat (PP 51-8) of the nownbook of 1600 and 1600 out of twenty-aght entrice only four aro ontrebly corroet, tour

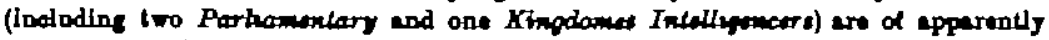

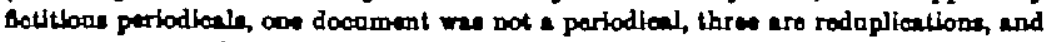
- rery footnote and oomment is efther totelly wronf or incorrect.

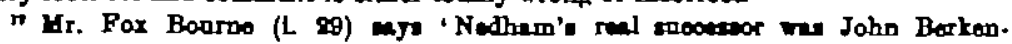

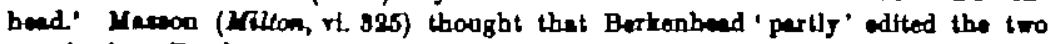
nemboaks But ho meraly llooneed them. Nothing more, oppoend to Berkenhend'? ityle then Moddimen's nowbooks cen well be conseived. Ho himenlt on Becrotery Nioboles's retiroment mys be 'coifered' nothing to come forth in tho nowlbooks

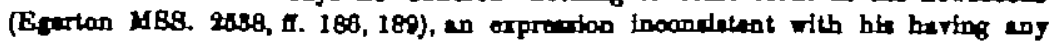

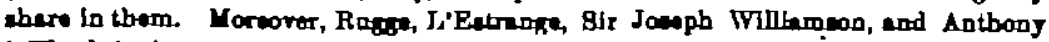
1 Wood (writer of Bartonhead's Iffe) all dietinotly theto that Moddimen wrote both nowabooke. Nearty twenty yearn aftor Moddiman's death the Britich Mackry, no. 869, for 80 July-2 August 1719, speating of this porlod, wye, "Tho Lemoul Muddi. men was then the only nemronger'. It abould be added thet Bortenhend was nover

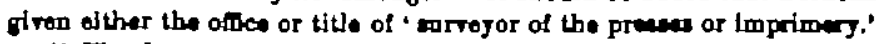

- The dete of A Rope for Pol from \& memoradam on the Brtifin Munam eopy (Wood quaries bls date) The profece to this peophlet with its Gollab of the

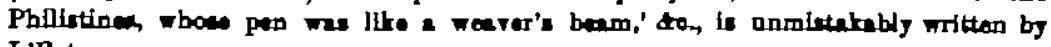
L'Eetrange. 
tho Afercurius Adlicus at Orford seventeen yoars previonsly, and (though this was not a periodical of general news) had therofore a knowledge of journnlism, and became (presumably under the Star Chember order of 1697, as the archbishop's deputy) licenser and censor of the Parliamentary Intellyencer nud Mercurius P'ullicus from this date. Secretnry Nicholas assumed the general control of the press, and the newsboohs were now published 'by orler' simply. But on 1 January 1659-60 the I'thamentany Intelligenrer camo to an ond with the convention parliament, and Muddiuan discarded that 'compellation,' as he contenptaously tormed it in giving his rensons for renaning it the hin!mlones Intelligencer. From this late both newsbooks wero markorl 'published by nuthority.' L'Estrange now lecnmo a great champion of the church of England in controversy with tho nonconformists, the presbyterians being tho specinl objects of his aversion, but in August 1661 bis clisgrusted Carcut to the Carcliers, incilentally recounting his services to Secretary Nicholns in Bcarching for disloynal pullications, again brought to notice the fact that neither preferment nor reward had been given to him.

At this time the' authorities were extremely ansious to snppress seditious $p^{x m p h l e t s ~ a n d ~ m o l i c e n s e d ~ p r i n t i n g, ~ a n d ~ i n ~ t h e i r ~ a n s i e t y ~}$ L'Estrnnge found his opportunity at last. 'Tles Stationers' Compnny had given grent clissatisfuction as being composeal of the dissentinators of disloyal books, nnd $n$ number of printers petitioned for incorporation and formulnted an elaborate scheme of proposnls and 1 egulations. " The signntories' names vere sufficient to secure its fnulure. It was decided to employ un orerseer or surveyor of the presses, and Thomas Dawks, stationer, petitioned for the office anil for poner to sentel for disloyal lrooks." On 3 Docemilser 1661 L'Estrunge nddressed nnothor 'npology,' this time to Lord Clarendon. Someone had accuset him to the chnncellor of lening sold intelligence to Crommell, and in the first paragraph of lis denial lie agnin berrited 'the maliec of my fortune, which has left me neither worke to fear nor much better to hope for.' ${ }^{11}$ He was

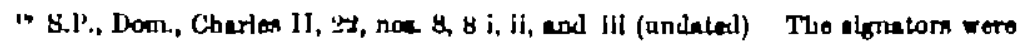
lite Houlgtineon (not Hutchinson), Joln Gramend, Nobert Ibbitcon, Thormes Mabb, Da Nexwell, Tho. Royerolh, Wm. Godbid, Ja. Btrenter, James Cottrel, John Huyes, and John BrodenelL All had been prinlers of newrboohe, end Jexwoll of the Nercariws fortdicen, for a inletake in which ho was ordered to bo enmmoned before perlienent on 25 Juro lice. Brodenell wes aftarwarde fimprixoned by L'Estrange. The docaunente ere mont carefully planned and thought out in oren detoil.

- Mid. rot. 48, na. 104 .

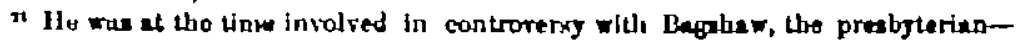

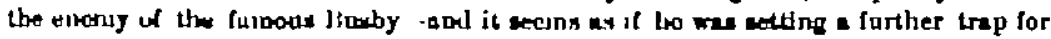
hur (in anoture paniplilat he edratted Llmelt suilty of 'propheneneses and dranken.

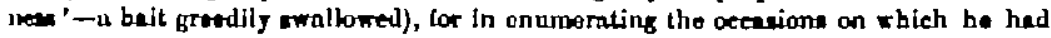
net Cromsell he orits to mention a mudeal party. Bugher at ones sare earrency to the spitefal ialeehood of his haring beon 'Oliver's fadder.' 
rewarded by being employed as ' Burveyor of the presses.' A general warrant empowering him to seize seditious hooks and their writers was granterl him on 24 February 1662." This he found insufficient, and nsked (in his capacity us 'Burveyor of the press') for a general gearch warrant also. It is to lo presumed that Secretary Nicholns acrupled to sign a documont of qucstionable legality and granting such arbitrary powers, for although one ras engroseed on parchment it was ncither dated nor executed." He must also havo been consulted with regard to the proposed licensing bill, an alsstract of which iв among tlie State Prpers." Another book followed on 11 Aprl 1662, entitled $A$ sIemento to all that Truly Rererence the Hemory of Kith/ Charlss the MIartyr, and was dedicaterl to Clarendon. It contained a large number of extremely controversial statements, and bitterly attacked Bagshaw. Bagrehew addrassed to Clarendon on 10 May 1662 a short letter in reply, in which he termed L'Estrange 'Cromwell's spy' and ' the Protector's enrrigge,' and furnished him with the opportanity ho desired for gaining notoriety. Truth and Loyalty Viuducated from the Reproaches and Clamour of Edtcard Bagshawe nppeared on 17 June 1662, and was dedicated to the privy council. In sirty-four pages of verbose and vituperative narration L'Estrange cleared himself, ender the controversy, and silenced his opponent. $\mathrm{He}$ was now a famons writer.

In May 1662 the licensing act was passed, and in Octolser Socretary Nicholns was superseled by the king's favourite, Arlington, with whom L'Estrange found gronter fnvour then he had with Nicholas. L'Estrange, as he says, was now employed to draw up proposals for the regulation of the press, and accordingly submitted a document in which he ngnin asked that the sarveyor of the press might be authorised to search and soize all seditions books, and in addition shonld have the control of all licensing (prith certain esceptions), and that 'for his pains' he should bavo 'the printing of all narratives and intelligences not uxceeding two sheets of peper' (i.c. the right of bringing ont the nowsbooks), 'and all bills and udvertisements, with a foe of 1s. per shect on other worke.' This not very modest demand was supplemented by the 'Minntes of a Project for the Proventing of Libells,' which was aimed at

I g.P., Dom, Chartes 11, 51, na.6. The solltary anofBois periodital, other then of adrertienmente, which attersptod to appoar betweon 1660 and 1 1B78 was $A$ Nonthly

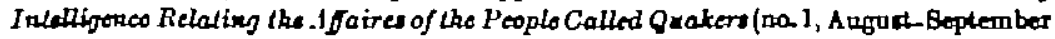
1669). Bome of the Noctrinale, do., howaver, ippeared.

D 8.P. Dorn., Cherles II, 89, no. 02, and rol. 51, no. 0. The wartant is eddresed to 'llowar L'Estrange Eeq, the survejor of the presen' and to not entared in the ontry book, as atetod by the Calezder. The minute of it-no, 10-does not annex Do. 10. 1, ' The Ninutee of a Project for Preventsog Libels,' nor hes it any connexion with the letter document.

It 8 P., Dom., Charles II, 39, no. 05. 
manuscripts, and by which he proposed to bring the written news rithin his grasp by ineerting a clause into the licenses of coffeohouse keepers." This led to an attack from Berkenbed, probably on behalf of Muddiman, rhom L'Estrange thus openly sought to supplant. Berkenhend (who had been appointed a mater of requests in January 1663) seems to have criticised verbally a pessage in L'Estrange's Mlomento. L'Estrange at once sent a memorandum to the secretary of state announaing that he had been charged by Berkenhead with writing book against the king, and that the king bad denounced him for it to parliament. He denied 'not only tho one and the other,' but with conaiderable epite carried war into his enemy's camp and obliged himself ' to a proof of more than that amounts to,' $M$ and, as usaal, turned the accusation to his further advertisement by publishing his remarkable Considerations and Proposale in order to the Regulation of the Press. This pamphlet was pablished on 9 June 1663 under the imprimatur of the chaplain to the archbishop of Canterbury and was dedicated to the king containing one epistle dedicatory to him and another dedicatory to the lords and commons. He alluded to the proposials he had been employed to drar, and, as might be expected, in the first epistle sttacked Berkenhesd, even accusing him of epesking egainst the king, and exhibited himself in his favourite character as a defender of royalt5.

In reward, and in compliance with his propossals, the surveyorship of the press was nor erected into an office and conferred on him by royal letters patent at the end of Angust 1663." His proposals wero cerried into effect, and in the eame patent he was constituted sole licenser of the press (with the exception of books on $\mathbf{l s m}$, divinity, \&c.), and among a multitude of minor things wo granted the sole right of writing, printing, and publishing newrbooks and advertisements. $A$ general gearch parrant was also conferred on him by it. He was not however given the fee of 1s. a eheet on books which he had also requested, nor had he power to interfere with manuecripts. Morcurias Publicus and the

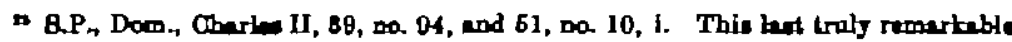
doeament informs ve thet the written newn was aleo sold by the etetioners, that writton libols were 'forty timm as meny' as tho printed ones, 'end by the halp of tranectpts vell-nigh an pableot as the other.'

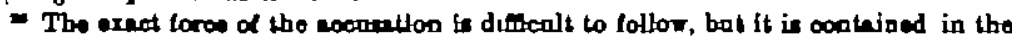
memorand om in L'Entrange' hendwriting and ggoed by bim, deted 81 Nerch 1683. 8., Dom., Ohertes II, 70, Do. 69, and an oxtrect endorned t the ounos of the affront

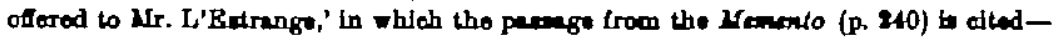
- atetement raforting to an ' nsofferablo ' affront to Chartee I (8.P., Dom, Chartes II, 28, no. 07).

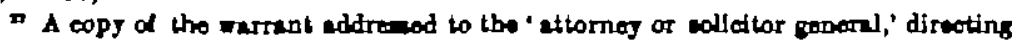
the dreving of the grant, it detod 15 Angat 1668 (8.P., Dam, Charter II, 78, no 98). This is not en order for a murent, es deworibed in the Calendor-en impartent difference. 
Kingdomes Intellegencer therefore came to an end with the month of August. However, Aluddiman's right of free postage (exaggeratiugly said to havo amounted to 4001 . a year-e great sum for the times) remained unaffected by L'Estrange's petent, and a similar privilege 'was denied' to the latter, who eventually cectred it 'by favour of the conntess of Chesterfield,' one of the farmers of the Post Office. ${ }^{\text {to }}$ He signaliacd the grant of his patent by obtaining a writ of quo ccarranto and the suspension of the Btatsoncrs' Company's charter until they had made terms with him.

The last stage of the newgbooks now began. Sir Roger L'Estrange entitled his Monday's pamphlet the Intelligencer (no. 1, 31 Angust 1663) and his Thurgday's edition the Naces (no. 1, 3 september). Though he had an office and a correspondence he supplied the printed news only, and the way in which he did it was very much in Afuddiman's favour as privileged newsletter writer. Whatever may be the defecta or merits of his pamphlets from a literary point of view there can be no doubt that as a journalist he was a complete failure. In his very first newsbook, after triumphantly announcing that the censorship and newrobook alike vere now in the hands of 'one and the same person,' he actually stated his objections to the publication of nerr and forecasted the appearance of only one newsbook a week. As if by way of earnest of what might be expected the number only contained six separate items of news, the rest consisting of the declaration of his views and intentions. On Monday, 1 Angust 1664, he gave notice that the Intelligencer would be discontinued after the 8th of that month; but this led to such an outcry that he had to abandon bis plan, though, as be somerwhat insolently remarked on 15 August, still reserving to himself a 'freedom of complying with what I shall find more commodious upon farther tryal.' Their scanty news was carefully spaced out and printed in large type. The two newrsbooks rere also consecutive, so that both had to be purchased in order to obtain the full news, and their eise was reduced by exactly one-half (to one theet of eight pages), withont eny reduction in price. By theso means he made them bring in treble the amount they had done in Muddiman's time. When war broke out with Holland in 1665 L'Estrange doubled the Nerees on 27 April, thus making it the same sire as its predecessor, the Mercurius $P$ ullicts. He followed suit with the Irtelligencer on $5 \mathrm{June}$, this return to the original sise being unaccompanied by any increase in price." As he eays that an 'overture' was nor made to Nedhem it

" Raffo (Brit. Jine, Add 18. 10117, f. 450) aya, 'In this month the newabook we written by oDe AIr. Roger L'EArange, a temour writor, end Noddimen put by al to thet employment.

- 8.P., Dom. Cherles II, 150, na. 61.

- Ibid. 125, no If The etatement in the profece to tho Calondar of 1085-6 (at In the Calondar iteolf) that he 'doubled the dise and price' is quite wrone. This lottar (91 Oetaber 1605) to mommariend bolow, p. 268. 
is evident that he was not satisfying official expectations as a pamphleteer. With regard to his news, his accounte of the naval battles left much to be desired, and he frequently hed to publish supplements, as in the case of the battlo on 8 June between tho duke of York and Tromp: ' all were disestisfied with his relstion of it. There was no account of the duke of York's eingular enconnter with Opdam; Prince Rupert was not even mentioned.' 21

At the time there were two 'principal eecretaries of atate;' Sir William Morice and Sir Edward Nicholas hed been fint appointed when the king came to his throne, and Nicholas had becn"superseded by Lord Arlington in 1663, as we have stated. Sir Joseph Williamson, keeper of the state papers (his knighthood cnme later), was also aecretary to Lord Arlington, as he hed been to Nicholas, and his principal left all matters almost entirely in his hands. There are numbers of letters addressed to him offering bribes for places, and the contempt with which his contemporaries occasionally speak of him shows thet this future principal secretary of state, if able, was not held in honour. He bad the business-like hebit of never destroying his letters and pepers. The lettors of intelligence which Williamson eent out at this period were mitten by Maddiman, whose letters from his correspondents were occasionslly and after a time usually addressed to Williamson's office. This would seem to have been the reason of Lord Arlington's request to Williamson to help L'Estrange on the latter's first toling oftice." At this time Williamson had no professional news correspondence of his own. ${ }^{\mathcal{D}}$ Daring the height of the plague Muddiman took Williamson's place in London, looking up treaties for Lord Arlington, and taking abstracts of Williamson's latters, but sonding the foreign letters to Williamson unopened, 'not knowing how it might be taken at court were he to view them.' ' One result of the general dissatisfaction with L'Estrnnge was that Williamson early in 1665 formed 'the design' of getting the 'public intelligence into his hands.' He ' - list ' of Muddiman's correspondents' names, but was 'refused,' and he must have known from his own experience in helping L'Estrange that it was not much use attempting to write a newsbook withont a wider correspondence than that which he then possessed. He therefore employed one James Hickes to obtain a list for him. Hickes was the clerk in tho Letter Office who usually signed suddiman's letters as franked. He was a servile, hypocritical creature who supplemented his official salary of $100 \mathrm{l}$. a year by

- B.P, Doch, Chertes II, 19t, no. 25.

- Ibid. 70 , na. 113.

n Mrid. 184, no. 118. 'I here rocedred of lete from Mr. Maddimen two letters of Intelliranoe, by your order, bo tolls me' (Dr. Rewlinson to Wriliemen, 16 Oetaber $1665)$.

"Ibed 183, no. 28, and 198, noce. 14 and 16.

s Ioud. 160, no. 149, peragtaph 8. 
himself sending out lettars of news. Mnddiman pas in the habit of presenting him with four copies of his own letters every week in order to help him in this. With the aid of this fellor, Williamson commenced a sordid intrigue, having as its objects the ousting of L'Estrange from his position as ofticinl editor and the obtaining of Maddimen's correspondence for the foundation of a new journal. His obrious plan was to relegate the latter to the position of salaried editor, and to obtain the surplas profits of both newabooks and letters of news for himself. In August 1665 Muddiman discovered that Hickes was writing to his correspondents, and suspecting his motives geems to have arranged for the bulk of bis intelligence to reach him unknown to either Hickes or Williamson, but parposely refrained from leaving the latter because ' while he was with him he [Williamon] could not send for a list of his correspondents to the office.'

On 6 October 1665 Lord Arlington received a grant of the office of postmaster-general for ten years, to commence on the expiration of the grant to Daniel O'Neale, deceased, and a reapon pas thus put into Williamson's hands of which he was not slow to make use. The plague had driven the court to Oxford. He decided to engage Henry Muddiman to write a new journal there. 'This would infringe L'Estrange's patent, but being done within the jurisdiction of the university there would be difficulty in stopping it. He himselt was a fellow of Queen's Colloge. The plan bad the additional recommendation that with Muddiman array at Oxford Hickes would have a better opportunity of copying the addresses of his letters and so obtaining the desired list of corre. spondente. Having made his arrangementa Williamson prote to L'Estrange from Oxford on 15 October 1665-

I am worry the distance in which we are from you deprives me of the occasion of helping and directing you in the composing of the publick newr, as would bo botter for his majenty's service and your own reputation. I have often sdrieed you to agreo prith Mr. Mladdiman in this matter, who having had the good luok and opportanity of falling into the channel of these things would hare been very nsoful to you, and in despair of seeing this effected in the future I take the freedom to propose to you that if you will relinquish to me your whole right in the composing and profit of the newbbook I will procure for you in recompense of it a salary from his majesty of 100l. per ennum, which thall be paid throngh my handr. ... If I plece it too low you mut blemo yourself for hering told mo several times that the daty of it is very burthensome and the proft inconsiderable.

On this L'Estrange wrote to Lord Arlington on 17 October, treating Williamson' letter as being from him, referred to the ' miscerriage' in public intelligence with which be says it charged him, and added- 
As to Mr. MInddimen, I did once make use of bim. I found him very short of intelligence, but it was daring Mr. Willeamson's stokneed, and that perchenoe might be the reason of it. Nor if MIr Williameon ponld be pleasad to engrage him to desl more openly with me I should take the meme afreement again for an obligation and immediately put that we beld atain in motion.

The consideration offered for the newsbook, he ssid, would " utterly ruin' him, 'it being come to above $400 t$. a year.' He had not complained of any loss over the newsbook, but 'of the excessive chargo of maintaining spys and instruments for the reducing of the prese, on which he oxpended $500 t$. the first year, and if Arlington hed not then charitably procared $200 l$. from the king for his supply he had 'found greater obstruction in the work.' On the 19th he again wrote n lengthy letter, reminding Arlington of his promise that he should not be dispossessed, when, before his patent had passed, he had forean what was now happening, and of the renewal of that promise 'upon the last occesion I had to trouble your lordship with this subject about the overture made to Nedham.' He had to satisfy a total debt of ' near 3,0006 contracted in the king's service.' And althongh he was as yet no gainer by his office, yet, however his friting was 'denied, even eccording to Mr. Muddiman's own calculation' the newsbook was then worth treble whet be found it. The 'quality of my employment,' he says, 'was to tease and persecute the whole rabble of the faction, which I have done to such a degree that I have drawn upon my head all the malice imaginable,' and the newrbook was given me 'to balance my ervice about the press; and in doing my work be judge, my lord, if I do not deserve my wages.' He was now 'marked out for beggary, infamy, and contempt, and briefly for the worst that can befall an honest man, and (to deal sincerely) without being informed of my offence.' Receiving no answer, he again wrote another long letter on the 21st, recapitulating what be had already anid and repeating that he had only complained of 'the charge for the service of the press,' and that eince then be had 'improved the book, and at length by doubling the sheet I doubled also the value.' From 200l. a year, as he found it, he had brought it up to above 500t., or $400 \mathrm{~L}$ at the worst. In offering to comply with Arlington's recommendstion of Moddiman he hoped to answer his duty of complying with the former's care of his composing his intelligence as he ought.

All this Fas in vain, for on Thursday, 16 November 1665," no. 1 of the bi-weekly Oxford Gasotte appeared, licensed by Arlington in direct infringement of L'Estrange's patent, printed in

- No. 1 wes got deted, but conteined nows inclunve of 14 Norember. It was not in London on the 16th (8.P., Down, Cherkes II, 187, no. 18), but had arrived on the 17th (Lbid. no. 24). No. 3 was deted for 16-30 November. 
Oxford by the Univeraity printer, Leonerd Litabfield, and reprinted in London by Thomas Nerroombe, the printer of the Intelligencer, ' for the use of some merchante and gentlemen who desired them.' The Oxford Gasette was but 'half a sheet in folio' of tro pagee. But the printing was much closer, in double columns instead of ringle, and the type much smaller. It at once 'gained grest reputation, for being in so small a volume it conld be sent anywhere.' "87 This remark, conpled with its size and sbape-that of the sheets of pritten news-and the title Gasette-an obvious reference to the fact-shows that it was actaelly intended to be ancillary to the letters of intelligance, and it represents the lowest etate of degradation of the printing prese. It was an open recognition of the fact that it was no longer possible to print news freely." The "general applanse' with which it was received " opeaks eloquently of the condemnation of Roger L'Estrange by the public.

The immediate collapes of his newsbooks stang L'Estrange into sn attempt to imitate the atyle of the Gasethe, and on Tuesdey, 28 November 1665 , be temporarily cersed them, and also published a 'psper'-Publick Intelligonce-closely resembling it in all pointa. He marked it significantly ' with sole privitege,' and commenced it by soying, 'By this time you may perceive, my mesters, that your Intelligencer has changed bis title, his form, and his day, for which I could give you trenty shrewd reasons if I were not obliged to gratify a point of prudence in myself.' The old Intelligencer was beck again however on Batardey, 2 December, and Monday, 4 December, and the Newes on Thursday, 7 December, as usual, the only difference in them aftarwards being that they were marked ' prth sole privilege.' He had no written news to send with them, and besides had found a better plan-he appealed to the king in person. Charles II could not very well refuse to protect so devoted a servant as L'Estrange, and ordered that, in addition to $100 l$. a year to be allowed bim out of the profits of the newrbooks, ' in consideration of their being taken into the secretaries' office 'a forther sum of $200 \%$. yearly should also be paid him by Lord Arlington out of the secret oervice money. L'Estrange, therefore, came remarkably wedl ont of the transaction and was pensioned with $300 \mathrm{~h}$ a year. He retained his patant with all its privilegen, and Williamson did not receive a grant of the newrbooks-they were 'taken into the

I B.P, Dom, Cherles II, 187, no. 00 .

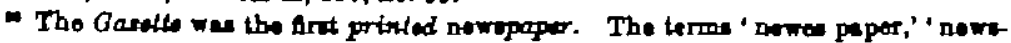
paper,' and (rwolting from them) 'nowalettar' rere nor gradtully erolved. Whoro

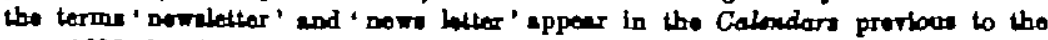

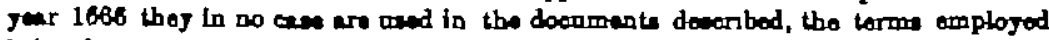

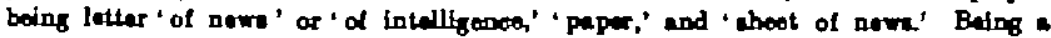
dinglo preos of peper, the Gantte conld not be celled a " nowbook.'

- B.P., Dom, Cherler 11, 157, no. 88. 
secretaries' office.' to Accordingly, after 29 January 1665-6 the Intelligencer and the Nerres ceased. The $300 t$. annuity was regularly paid down to the end of Arlington's tenure of office, but fell into nrrear when Williamson succedes him. L'Estrange bud to appeal to the attorney-generul and the solicitor-general, and his doeuments nero 'fraudulently conveyer from him, taking alvantage even of that opportunity,' i.c. in 1680 , 'that forced him out of the kingdom for eafety.' 11

Daily during the reak beginning Homlay, 27 November, and ending Baturday, 3 Decomber, Hickes took lists of the addresses of Middiman's correspondents and Bent copies of them to Williamson, remurhing on 3 Decamber that he left to him the 'management' of them. These lists, showing correspondente in Paris, Antwerp, Scotlend, and Ireland, prove how far-rorching and important the correspondence was. Muddiman wns warned of Hickes'e proceellnge, and despalched his letters for the future under cover to unother clerk in tho Letter Oflice, Edmond Sawtell. AB a consequence of this Hickes wrote to Wilhnmson on 10 January 1665-6, a letter which he terminates with a prayer for ' $\mathrm{n}$ contented heart to live to God's glory,' and in the postecript makes tho renomons suggestion-

I do still pray you to write two or threo sunart words to tho parpote that my lord understands I detain the king's letters longer in my hand. then I ought ... . Tho renson I hint this much is MIr. Mraddiman's agent, Mr. Sowtell, when I am going suddenly to make up [tho lotter bag] gallops to tho tavern whonce I must send for him to make op Mr. Aluddimar's . . . And as I am informed he [MIddimen] threaten. mo, ns yet I dare not send array my lettors whthout his; if I do I shall bcar of it to some purposo . . . . If I stray a lusir's brealth beyond my lord's ordors snd yours-hang me.

On 19 and 16 Jnnunry Sir George Downing laad written to Williamson that ' $\mathrm{a}$ friend' had said

his instrument was discontentod and wislied to go to Bocratary Mlorice and carry him intelligence, as be hed done to Williarnson, and thus help the othor Garelle

(the newsbook being taken into the secrelaries' office there was nothing to prevent both sccretaries issuing one), but was 'stopped for a time,' telling him to maku use of the information 'to keep him to you.' Williemson at once ordered Hickes to stop the letters to Muddiman, for on 17 January Hickes writes that he has done so. There then was some attempt on his part to patch up an arrangement, for on 20 January Hickes prites that he at all times trents Mr. Nuddiman with respect, and aftor snying that he personally had not

\footnotetext{
- Ormonde JiSS rol ib. N.S pp. 381, M3. Cesse of Roger L'Eatunge and certibente of Lord Arlington.

" Toud.
} 
had a line from him for a long time (meaning the gifts of sheets of news had been stopped) admits that he had been opening his letters by saying, 'I do perceive what bombast he writes,' and concludes-

I do therefore hint thas to you, that exeept his sarvices to you be orned very amply it will not suit with your interest and interest of this offco to pess his lettore free to the value of four hundred pounds a year to the king's mocount.

The king retarned to Hampton Court on 27 January, and to Whitehall the following reek, so that the last number of the Oxford Gazette (no. 23) appeared at the end of January. The continuing peper was called the London Garette with no. 24, and after no. 25, published on Thursday, 8 Februnry 1065-6, Henry Maddiman declined to write it. ${ }^{42}$ Williamson could not write the Gazette himself. He therefore crlled in Charles Perrot, of Oriel College, who Anthony is Wood saye wrote the Gazette, though not constantly, until about 1671 . Pcrrot, in bis reply to him dated 4 February, arranges to hee him on Vednesday, the 7 th.

Maddiman now directed all his correspondents to send their letters to him for the future at the office of John Cooke, Becretary to Sir William Morice, and handed Hickes Becretary Morice's order for free postage. There is among the State Papers a letter of his (with the address defaced), dated 16 February, giving theso dircetions; and therefore the initiative came from him. He saw Hickes the same day, to make sare of the matter, and promised Secrotary Morice's 'general order' on finding that he disputed the other' suffliency. ${ }^{12}$ But Williamson had determined to make another attempt to secure the correspondence now elipping out of his hands, and so Hickes is found writing to him with a sample circular on 14 February, 'that you may view and judge the fitness of communicating some part of the eame.' There are tro copies, one of Fhich is dated 13 February and the other 13 and 15 February, and it ras eventually sent round by Hickes to Muddiman's correspondents. Willismson before causing this to be done must have decided to set the two principal secretaries at variance and to trust to Arlington's greater influence with the king gaining the day orer Sir Willism MIorice.

The circular states that Aluddiman, whose letterg had formerly come franked to their hands, was

dimisted from tho management of that correspondence be formerly res instructed with for that be hath contrived and maneged that correspondence to his own particuler adrantage and not for the service of his majestie and those perzons of hanour [Arlington and Villinmson] as he ought and they oxpected be should hare done.

a The tast number written by him be tixed by his cirealer of Suturday, If Febraery, infra, p. 870.

- G.P, Dom., Cherles If, 160, no. 140, paragreph 7. 
and concludes with a broad hint that Hickes himeelf was prepared to supply his place in assuring them of 'that respect upon your commands eo far as in my porer.' Hickes at the same time wes careful to meet Bir William Clarke, Monck's ecretary, in the city and to retail to him the esme false account of a dismisoal. It appears from a memorandum at the foot of one of the tro liste of correspondents that Williamson wrote to 8 fer.of them himself, but there in no copy of his letter. When Muddiman heard of this he went in a 'great huff and heat' and ordered Hickes to reanll his circular, and on his refusel sent ont (24 February) a circular of his own, contemptrously terming Hickes a "little fellow of the post office,' and anying that

apon a misunderotending between Mr. Williemmon and myrelf about the Gaselte, which I wrote at Oxon and till the lest week at London, I thonght it most advisable to quit that offoe wholly [i.e. the Btate Paper Offioe] and torn my correspondents to Bir Willism Morioo, his majesty's firat principel sectetary of Btate. I shell write es fully and constantly es formerly and with the same privilege and poet-free.

He adds that he had detected Hickes in ' gome practices,' had not entrusted him with his letters to sign,

nor given him, as formerly, a copy of my letters to write after, but as be is disowned in it by thoee he protends orders from to I hell mako him samsiblo of the forgery.

The forgery was, of course, Hickes's attempt to pass off his own neweletters in lieu of Muddiman's privileged ones. The bed faith of the first circular is rendered clesrer by the correspondence being immediately continued, nother Letter Office clerk, Hall, signing the letters as franked.

On this Hickes eddreased a formal petition' to the two 'principal secretaries of atate,' hypacritically protesting that he had discharged bis daties 'as in the presence of Almighty God' and asking that Muddiman might be ordered to 'repayre' him for the obarge of forgery (to which he was careful to attach a wider meaning than that plainly intended). This was not a wise step. Hickes was ordered to state his case, and drew up in numbered paragraphs his lengthy ' Narrative of the Dibcourse betwixt Mr. Henry Muddiman and James Hickes, senior, concerning his Correspondence.' Like the petition this docament could not possibly have been drawn up by Hickes unaided, and it is chiefly remarkable for giving the bistory of what had bappened, from which the preceding story hat boen in part taken. Its probable date was the end of April, when Sir William Morice decided to take action. In it Hickes reiteratod his accusation of a dismiseal, abandoned his charge of Muddiman'a continuing the correspondence to his own advantage, and tacitly admitted thet he was entitled to do so. He edded a new incolpe- 
tion of sending out letters of other business in which neither the ling nor himself was concerned, to the end that they might go free, pointed out the large number of lettere he despatched, and, after accusing him of sending out nothing but the common newsbooks, alleged that there was ' not one letter in answ er to most of the letters he sent, receiving yearly stipends of from 40s. to 40l. per person,' and admitting that he had intimatod his intention of preventing his despatching his letters before the Garette, said that it was his ' Bcandelous circular' which oceasioned his 'homble petitioning.' 'Throughont all this, Williamson appears to have kept himself in the background and to have ' disowned ' Hickes. It is only from Hickes's letters to him that he is revealed es the actual instigator. The accusation of sending out nothing but the newsbooks was well calculated to cause mischief, as the clerks in the Lettcr Office by an abuse of their privilege of free postage were accustomed to do this, selling them at a large profit.

In the meantime Secretary Morice, finding that there vere renewed attempts to interfere with Muddiman's letters, 'took it ill and required an account of it,' although Hickes wrote confidently enough on $25 \mathrm{March}$ (1665 in mistake for 1666)-

$I$ long as a women very big to know my lord's resentment and yours as to the bariness of my petition, and I expect a vindieation or 2 judgment, with punishment if guilty, of what he heth calumninted me with.

A complaint by Hickes to Willinmoon on 9 April was that Bir William Morice was described as first principal secretary of state, which was not unnatural in the circamstances, and, owing to his seniority, was etrictly true, and Hickes wished 'his lordship' (Arlington) 'might not be thus reflected on longer.' "1 Secretary

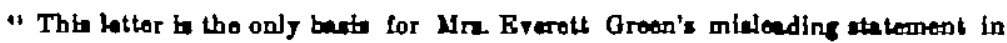
ber preface to the Calendar of State Papars, Domestic, for 1686-6, that Yuddimen

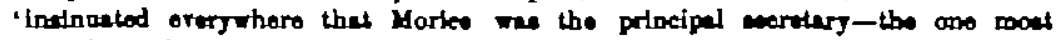
trueted by the king.' Mra. Groen's other remerta to the effect thet Maddimen

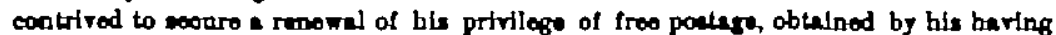
been 'new-callector' to L'Estrengo, thet IVtliemeon vrote on 18 Ootober to L'Eatrange ' declining an epplication for atdetanos In collocting ners,' and that ' the oditorabip was hended over to' him ere all equelly anoupportad by the documente. Eupoinelly is this the ease in regard to her atetement is to a comparteon vith Frande's newalottors. Indend, this rolume of the Celonder eannot be acosted as

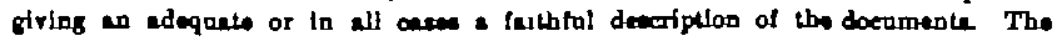

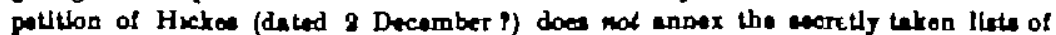
correpondents: it ennexes Hiotes'e cirouler of 1s-15 Fobrasty, and rators to Yaddl. man's cirenter of 24 Febriary, end is therefore thres monthe later in date. The

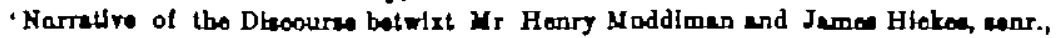

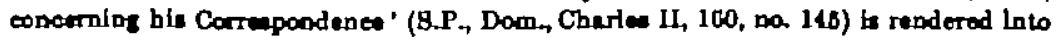
'Btatement by James Hibles of his Comerponderes with Hent Moddlman, and the

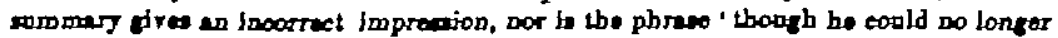
we private lettorn' in the originel.

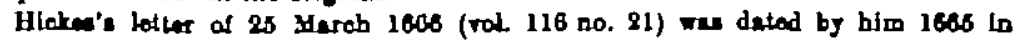
musteke, boing the Kow Iner's Dey of the times. 
Morice's influence wes evidently get at nanght. But the powerful under-secretary had miscalculated the strength of the adversary he had to deal with, and the resalt was a severe defeat. Sir William Mforice at last took action, and in a manner that was a public rebake to IVilliamson and completely silenced Hickes.

Maddimen was nuthorised to write a second official printed 'paper'-Currert Intolligence. This appeared in open opposition to the Gaxette (to which it was similnr in all respects), end on the anme days (Bondays and Thargdays), ander Sir Willinm Morice's licence, and the first number was dated Mfonday, 4 June 1666. The printer was John Macock." In January the next year Morice opposed Williamson and secured bis rejection when he attempted to enter parlisment as member for Dartmouth, obtaining the election of his orm candidate instead. No. 6 of Current Intelligence contains a carious announcement, from which it may be concluded that the Gazette also was never intended to contain adrertisoments.

The pablication of books, medicine, and other sach thinge being remote from the business of a paper of intelligenos [the term also applied to the writton news], this is to notife that wo will not charge the intelligence with advertisemente, anless they be matters of state, but that a paper of edvertinements will be forth with printed apart, and recommended to the pablio by enother hand.

A similar announcement appenred in the Gcrette on $17 \mathrm{June.}$ L'Estrange bowever actod on his patent and at once stopped both by isouing a pamphlet called Publick Advertisements on 25 June. This characteristically greedy enterprise failed and was his lagt esagy in journaliem. "t That the management of Current Intelligence Tas enterprising is evident from Hickes's letter to Williamson on 8 Angust 1666 , in which be sayg-

Mr. Meoock and Mr. Muddimen gare the 'bookwomen' [i.e. the promen employed to sell the papen] 20s. each, invitod them all to Horney to his house to dinner, and provided them cosches to take them there and beak. L'Eatrange gave them all monthly a quire of books and quarterly 53. enoh; to enconrese them in bis service. Br. Newcombe [the printer of the Gasette] only gavo them 10s. emongat them lest quarter. [Ho] hoped Williamson would be as good a mastor to them is L'Eatrange was: they kner the single Gasette far oxooded in profts L'Estrange's double wheots.

The ponition of the Gazette now became very serione. It was

- Hist. Sanweripts Contmission, 10th Rep, app. Ir. P 119 ; Fleming, Cal. p. 10 (761); Statsaners' Regittr

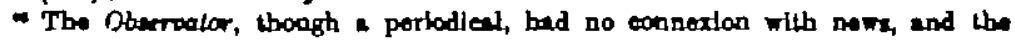
advortisement aheots called City Bferenria (mome written by Oliver Williems, and the Arat in 1607 by Thomes Bromhall) were meroly licenned by bim, aod prabebiy had to pay bill for the pirflege of appearing. 
saddled with L'Eatrange's 100l. a year, and thero tras Perrot's salary to be paid, which at the rate of the times must have been about 200t. a year. If it had held the field nnopposed there would have been, on L'Estrange's probably too farourable eatimate of $400 \mathrm{l}$. a year, no very great margin. But it had an unstilled writer, with the ablest journaliat of the day actively hostile to it and powerfully supported. Williamoon also had to organise a news-letter correspondence for the trofold purpose of competing with Muddimen and of supplying the Gazette with news. In spite of a considerable number of payments for ners, ${ }^{77}$ and the alienstion of one or tro correspondents by the diatinctly fraudalent means adoptod, he failed in both objects. The Gasette was rescued from extinction by an accident. In the Great Fire of London, which began on 2 September 1866, the printers of both the Gazette and Current Intelligence were burnt out. Both papers stopped after Monday, 9 September. When the Gaxette reappeared on 10 geptember (being printed for a time in an evil-smelling churchyard) the other paper did not. There was not room for two conflicting offlcial papers and there must have been a question as to whether L'Estrange's annuity ehould be shered botrieen them. Probably Williamson obtained terms orer this. In any case the purpose of Current Intelligenco had boen served, and it was clear throughont that Maddiman did not desire a neквpeper crippled and hampered by restriction, bat the untrammelled and far more profitable newsletters. ${ }^{20}$ The Gazette romained alone, the last of the government 'diurnals'-surviving in our own times-henceforth to exiot solely by reason of its official position and foreign newrs.

Bir William Morice resigned his office at Michaelmas 1668, bat there is every evidence that Muddiman's pririleged position as official newsletter writer was not cartailed by the loss of his right of free postage. His newslettar correspondence was organized on a Bcale the like of which had never been goen before, and became so lerge that it attained the dimensions of en institation." William. en's efforts to compete with him were fatile, and the Gaxette itself

" Although the gift of 81, on 0 Angut 1660 (8.P., Dom, Chas. II, 187, wa. 57), mot to bls new sement, Biler Teylor, at Harwioh for distribution among the roonded

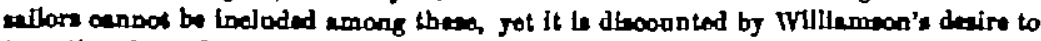
ingratinte himalf with Monok and the fuct thet ha hed disiseulty in abteining corre. epondente In the peighbouthood. Tho 'notelity and gantrg' thought ' all boidnen of

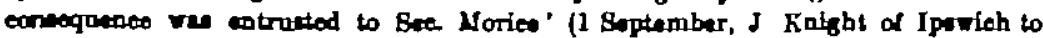
Williemanon, ibid 176, na. 8).

- On 17 Oetobor 1666 the bous of commons eppointed a committo to inguire

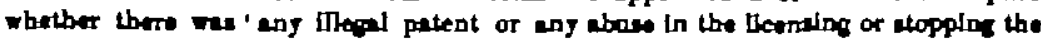
herfal printing of booke' (Comprows Journalo).

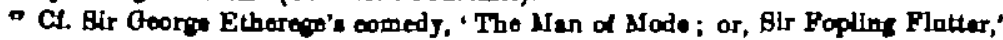
aet il mene 2 (1676); Ropor North's Lufo.of Sir John North; Wood's Life and Timet, by Androw Ctart, if 152, fii. 88, 191, 156, 180, and 208; But. Haxueripls

POL IXII.- - HO. IO. 
was well-nigh crushed out of existence by his written nexs. From all parts of the country complaints of the Gazette now reached Williammo, and with onfavourable comparisons. When Muddiman's newsletters appeared the Gazette 'was never anked for.' Peoplo 'declined the Gasette' in favour of his newaletters, nnd 'persons of the greatest quality' weru : constrained to betake themselves to them.' The newsletters were 'much noticed, cliefly as communicating the diurual debates and proceed ings in parliament.' Не was begged to ' enlarge his ners.' w

On 27 December 1667 Hickes himself admitted that there was a general complaint of the Grzette wanting domestic intelligence, and that some in the office who sent fourteen or sixteen dozen weekly, then only sent half the number. Trenty dozen less than formerly were sent.

The people so much slight them, they having notking in them of the proceedirgs of parlianient, which MIr. BIuddimen writes at large. Wero there bat as muoh printed as he writes it would keep up the Gasette far begond what it now is. Mr. Muddiman gives far larger aceounts to his correspondents thun you do, which make them much desired.

There is the same tale the following year, for on 20 Augugt 1668 Hickes wrote-

Mr. Newcombo prints not above ane-half he before printed, which in tume they bope you will find a ray to help.

Hickes's own privilege of free postage, and therefore the bulk of his profits out of the Gazette, vanished. Sir John Bennet, the deputy postmaster (not, it may be suspeted, without instigation) ibsned nev rules in 1667, under which the clerks in the Letter Office were for. bidden to send either their own letters or copies of the Gaxetle free. Hickes clamorongly protests in a series of complaining letters to Williamson that he 'shall take his leave, hve apon salt and water, and rest upon God,' as be gets 'not a candle nor a cup of beer, as formerly granted, and the taking avay of the poor petty thinga.' He had receired nothing from IVilliamson but 'fair worda.' Previously to this time he has, as he says, eent out thirteen dozen copies of the Gazctie on Thursdays and fifteen dozen on Tuesdays, 'for which some pay $2 d$. or $3 d$. ench.'

It is cartain that Williamson's own newaletter correspondence

Commierion, 4th Roport, Appendix, p. 250 ; Th Roport, Appendix, p. 108; $121 \mathrm{~h}$ Roport, App. 1x. p 77, de. In 1077 Luddimen was errestod lor writing thet the

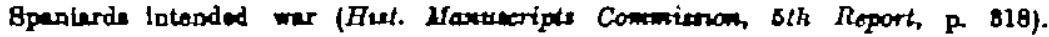

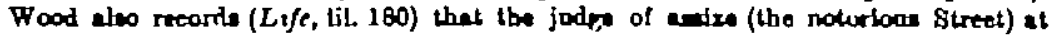
Ortord ehargad againet aewaletters pertientarly Noddiman's, in 1686, in the dage of Jame II. His lottere were utopped coning to Oxford, ' yet other trito and lying lettere

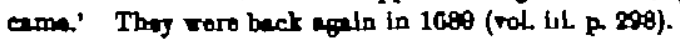

- 8.P. Dom., Charlea II, 176, no. 160; 179, no. 21 ; 198, no. 84; 205, no. 85 ; 207, no. $180 ; 214$, no. 128 . 
an actual lose to him. The report to him of his ohief olerk, H. Ball, while he was in Holland in 1674, states the grose income for the year ending that Michselmas as amounting to $174 l$., of which 120 l. was paid in eslaries to four copying clerks, $9 l$. 12s. Fent for office expenses (not including rent), and the reat he retained for bimself, whether in full antiofaction of his claims or not does not appear. He makes complaint that eubscribers are uncertain in their peyments, and that the payments to correspondents and other expenses are not shown." To what expedients Williamson resortod may be seen from the numbers of Maddiman's newsletters to be found calendared among the 8tate Papers from 1666 for many years onpard. Thoy are all addresed to different persons at various dates (all letters of news so addresod almost without exception being by him), and were intercepted in the poet by Hickes and forwarded to Williameon for his ase in making up the contents of the Gasette and his own newsletters. There are many veiled references by Hickes to what he was doing, and in the sutumn of 1668 , when Williamson was staying at the countess of Thomond's at Billing, near Northampton, he supplies an open proof. He had written on 20 Auguet,

I am gled I guit with your opinion and sense concerning the partionlar letters nor and then sent you, of whioh I shell sey no more,

and on 7 Beptember commenced bis letter by saying, 'I sent yceterday a letter for you with two enclosed of H. M., and desired Mr. Francie' (then Williamson's neweletter clerk) 'to send it to you without opening it.' sx

Henry Muddiman died at the beginning of the year 1698 and was baried in Kensington Parish Church. There is a complete collection of hif newrletters from 29 Aprl 1667 to 12 October 1689 in the marquis of Bath's library at Longleat. Their datesare on alternate days and they are contained in fourteen folio volomes, formerly the property of his wife. This collection of some thousands of consecntive nembletters by one person, is quite unique, and,

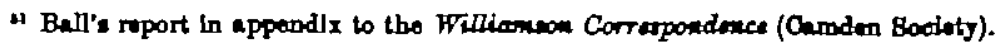

- 8.P., Dom., Oharles I, 946, noe. 7 and 190. Thes statemente are comitted in the

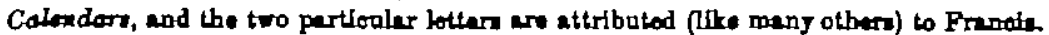

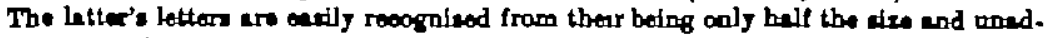

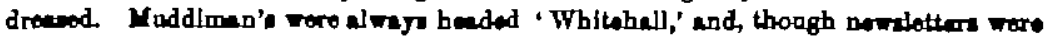

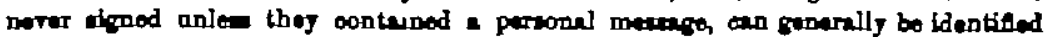

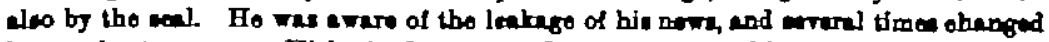

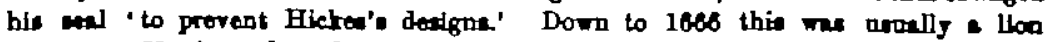
rumpent. He theo edopted a new device, on socount of Hickes's thefte, whioh may be dencribed in foar crowes radiating from antre (rather than a cracele), with - oiralo roond ach lowrar limb. From 1870 bo ued the Penlett erme end orest, differmood by a eremont. Ble offles wes firat at the Beren Btere end aftarward at tho Peacock, both near the Now Brehenge, in the Strand, end hil privato boow was

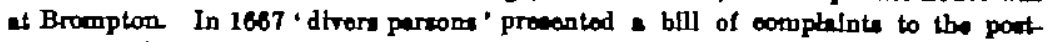
menter wh regard to the 'opaning' and 'misoarringe' of lettern (8.P. Dam, Chartes II, 921, no. 4). 
considering his privileged position, should be of high value when alendared." $\mathrm{He}$ identified himself with the large number of thoroughly loyal but disgusted royalists who became known as the 'country party,' of whom bis protector, Sir William Morice, was a type. Dry and didactic, his style of writing was altogether lacking in the forcibly picturesqne verbiage of that arch-controversialint L'Estrange; and yet, as the public reliance on him shows, he was infinitely more connistent and trustworthy than the despicable Nedham. As journaliat pare and simple he was the greatest of the three, and dealt with facts rather than opinions; indeed, his avoidanco of the latter is noticesble. His permanent memorial will almays be the London Gazette, to which he gave its form and the actual appearance which it retaing to the present day.

\section{J. B. Whunus.}

- On 23 Docember 164 the bouse of commone resolved thet no nemettor writarn do, In their letters or other pepers, that thoy disperse, preanmo to intermeddle with the debates or eny other procedinge of this houne ' (Corarrors' Joumals). 